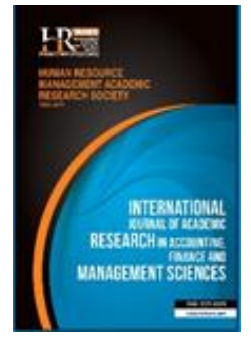

International Journal of Academic Research in Accounting, Finance and Management Sciences

Vol. 10, No.2, April 2020, pp. 304-316

E-ISSN: 2225-8329, P-ISSN: 2308-0337

(c) 2020 HRMARS

www.hrmars.com

To cite this article: Al Shbail, M. O., Al Shbail, A. M. (2020). Internal Auditors and Internal Whistleblowing Intentions: Evidence from Jordan, International Journal of Academic Research in Accounting, Finance and Management Sciences 10 (2):304-316.

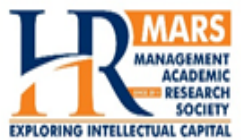

\title{
Internal Auditors and Internal Whistleblowing Intentions: Evidence from
} Jordan

\author{
Mohannad Obeid Al Shbail ${ }^{1}$, Awn Metlib Al Shbail ${ }^{2}$ \\ ${ }^{1,2}$ Department of Accounting, Faculty of Economics and Administrative Sciences, Al al-Bayt University, \\ Jordan, ${ }^{1}$ E-mail: mohannadobeid87@aabu.edu.jo (Corresponding author)
}

\begin{abstract}
This paper is intended to examine the influence of the dark side of leadership and organizational commitment on Jordanian internal auditors' whistleblowing intentions. The study utilizes a sample of 89 selfadministered questionnaires from internal auditors working in Jordanian public industrial shareholding firms. The statistical package programs SPSS 24 and PLS 3 were used for analyzing the data. Descriptive variables statistics were performed on the SPSS program and model testing in which the effects of the dark side of leadership and organizational commitment on the whistleblowing intentions were studied was performed using path analysis technique in the PLS 3 program. There was a negative and significant relationship between the dark side of leadership with organizational commitment and internal whistleblowing intentions, according to the study results. There has also been a positive and significant relationship between the organizational commitment and the internal intention to whistleblow. All of these support the mediating role of the organizational commitment in delineating the link that exists between the dark side of leadership and the whistleblowing intentions of the internal auditor. The study can help firms develop effective mechanisms for whistleblowing. In an emerging economy, this study provides evidence of the influence of organizational commitment and leadership behaviour on whistleblowing among internal auditors.
\end{abstract}

Key words

Whistleblowing Intention, Organisational Commitment, Dark Side of Leadership, Internal Auditors, Jordan

\begin{tabular}{rcl} 
Received: & 12 Jun 2020 & C The Authors 2020 \\
Revised: & 18 Jul 2020 & Published by Human Resource Management Academic Research Society (www.hrmars.com) \\
Accepted: & 10 Aug 2020 & $\begin{array}{l}\text { This article is published under the Creative Commons Attribution (CC BY 4.0) license. Anyone may } \\
\text { reproduce, distribute, translate and create derivative works of this article (for both commercial and } \\
\text { non-commercial purposes), subject to full attribution to the original publication and authors. The full } \\
\text { terms of this license may be seen at: http://creativecommons.org/licences/by/4.0/legalcode }\end{array}$ \\
\hline
\end{tabular}

\section{Introduction}

Whistleblowing is the practice of divulging unethical activities, internally or externally, affecting an entity or its leaders (Chiasson et al., 1995). Whistleblowing is an efficient tool for identifying and reporting bribery, unethical activities, and other corporate wrongdoings and the auditing and accounting profession plays a significant part in the whistleblowing process. Accountants and auditors are likely to witness fraud related to accounting, thereby giving them the ability to blow the whistle on wrongdoing (Liyanarachchi \& Adler, 2011; Miethe \& Rothschild, 1994). Whistleblowing on accounting-related fraud has been an important topic in academic journals (Alleyne et al., 2013; Carcello et al., 2011; Dhamija \& Rai, 2018; Read \& Rama, 2003; Smaili \& Arroyo, 2019; Xu \& Ziegenfuss, 2008) demand more accounting studies on whistleblowing. Read and Rama (2003) contend that the role of internal auditors in whistleblowing needs to be reviewed further. Whistleblowers that have greater integrity and leverage than other leaders of the company are likely to influence the management to end corruption (Near \& Miceli, 1995). Internal auditors could possess these two elements in practice, and should therefore be more likely to whistleblow (Ahmad, 2011). According to Ahmad (2011), the duties for maintaining good corporate governance practices also 
involve the need for internal auditors to whistleblow directly within their organizations in the event of need. Previous studies showed that there are limited studies of whistleblowing which used internal auditors as subjects (Ahmad, 2011; Ahmad et al., 2014; Arnold \& Ponemon, 1991; Habbe et al., 2019; Miceli et al., 1991; Xu \& Ziegenfuss, 2008; Zheng et al., 2019). This could be due to arguments that the role of internal auditors reporting corporate misconduct is not considered a whistleblowing act. These studies show that whistleblowing in the field of auditing should be investigated thoroughly, and the act of reporting by internal auditors may be considered as internal whistleblowing.

Internal auditors' function within organizations is different from that of external auditors, since internal auditors are company employees. The internal auditor has historically had a major duty to review and comment on the quality of the accounting and financial reporting processes of the company internally (Kwon \& Banks, 2004). As a result, internal auditors will also face conflicts of interest where the management action or purpose is not in accordance with the requirements defined by the profession. The problem here is that internal auditors should report their conclusions to higher officials (i.e., blow the whistle), such as the audit committee/board of directors, or let them go side by side with their superiors.

The literature indicates that organizational commitment has a significant and constructive impact on whistleblowing (Kurtz et al., 1981; Miceli et al., 1991; Taylor \& Curtis, 2010). A loyal and dedicated employee can be argued to report internally in order to avoid harm to the image of the company (Near \& Miceli, 1985). As a result, individuals with a high level of organizational commitment are more likely to exhibit pro-social behaviour than those with a low level of organizational commitment (Brief \& Motowidlo, 1986), through the concept of organizational commitment, to internal audit activities. Ensuring that internal auditors believe the company trusts them and can rely on the company is shown to result in increased organizational commitment of the internal audit department (Kwon \& Banks, 2004) and can continue reporting internally. Therefore, it is in the interests of both the employee and the internal auditing profession to better understand certain factors that lead the internal auditor to commit to both his/her organization as well as the profession (Kwon \& Banks, 2004).

Work on determinants of the commitment of internal auditors, therefore, offers useful practical information along with an extension to the current literature. According to (Weaver \& Yancey, 2010), the researchers had a strong interest in the effect of dark leaders on the organizational commitment of the employees. In the past decade or so, the "dark side' of leadership has been the focus of extensive study. Researchers have classified "dark leaders" into many catogrized as toxic (Bhandarker \& Rai, 2019), abusive (Tepper, 2000), bad leadership (Kellerman, 2004), unethical leaders (Treviño et al., 2003), aversive leadership (Bligh \& Hess, 2007), and destructive (Einarsen et al., 2007). Some of those leaders' frequent actions are ridiculing and insulting staff, lying and deceit, blaming others for their errors, abuse, and physical violence. In addition, this kind of leadership is correlated with a reduction in organizational commitment of workers (Hoobler \& Hu, 2013; Tepper, 2000).

From the previous discussion, it is clear that the dark side of leadership contributes to behavioural and attitudinal consequences; this research focuses on the idea of the dark side of leadership, which generally refers to the degree to which subordinates view themselves as the recipients of hostile treatment from their superiors (Tepper 2000). In organizational behavioural research, the impact of abusive supervision by "dark leaders' on employee deviance has been extensively reported (Guan \& Hsu, 2020; Tepper et al., 2009). Nonetheless, work is required to understand the impact of organizational commitment in internal auditor's responses with respect to whistleblowing intention due to the dark side of leadership. Motivated by the void found in the literature, this research uses the Planned Behaviour Theory to examine factors that affect the intent and actions of the Jordanian auditor towards whistleblowing. Jordanian internal auditors have been chosen as subjects because regulators attach significant importance to them in the design, implementation, and evaluation of internal control systems based on preventing misconduct and improving ethical standards (Institute of Internal Auditors IIA, 2016). In particular, the IIA requires internal auditors to fulfill their duties to promote a good ethical organizational culture by periodically evaluating the efficacy of the ethical standards of the organization. Especially, internal auditors are prone to whistle-blowing as they are expected to disclose any misconduct either inside or outside the usual chain of command (IIA, 2016). Not revealing suspected misconduct is considered unethical because it contravenes the Code of Ethics of Internal Auditors. Therefore, the present study aims to add to the recent 
debate about the dark side of leadership, organizational commitment, and internal auditors' whistleblowing purpose in the sense of Jordan. The rest of this paper's discussion is organized as follows: Section two reviews the previous literature and develops the hypotheses. Section three of this research addresses the approach to methodology. Section four introduces and analyzes the empirical evidence, followed by section five, which elaborates conclusions and discussions. Finally, section six summarizes the conclusions and provides suggestions for po-tential investigation.

\section{Hypotheses Development}

\subsection{Dark side of leadership, organizational commitment and whistleblowing intention}

The dark side of leadership is the other side of the conventional notion of leadership that gained numerous nominations such as aversive leadership or destructive force in corporations, abusive supervision, destructive leadership, and toxic leadership (Bligh et al., 2007; Einarsen et al., 2007; Kılıç \& Günsel, 2019; Tepper, 2000) among others. As can be seen, this approach can be extended to the individual exercising leadership in organizations, and to the conditions or processes created and encouraged by this form of leadership. Dark managers or bosses are detrimental from a broad viewpoint, and use negative tactics to control their subordinates or followers (Krasikova et al., 2013). Such leaders tend to be aggressive and act both verbally and nonverbally hostile (Tepper, 2000).

Traditionally, leaders have been conceptualized as a significant relational element that cultivates or stifles the commitment of employee and organisations (Chen et al., 2019; Guan \& Hsu, 2020; Kim \& Shin, 2019). While current literature has not explored the impact of the dark side of leadership on organizational commitment and whistleblowing purpose, a small but growing body of dark leaders research has shown that exposure to coercive oversight results in the reluctance of subordinates to "go the extra mile" to conduct activities that favor their organizations (Zellars et al., 2002). Researchers have explored the effects of leadership on the dark side, including the negative work-related behaviours of subordinates and violent, resistant, and deviant organizational behaviours. Studies have demonstrated that the dark side of leadership is a detrimental organizational commitment (Duffy et al., 2002; Kilroy et al., 2016; Tepper, 2000).

Recent studies have shown that exploited subordinates felt that their boss cared less for their wellbeing and were unable to associate with or grow a sense of loyalty to their organization; further, low affective commitment workers who encounter coercive leadership showed greater deviance from organization (Aryee et al., 2007; Tepper et al., 2008). In line with these notions, this study contends that dark leaders will affect perceptions of the responsibility of internal auditors to stay and the costs and benefits of leaving, resulting in low organizational commitment. In other words, internal auditors prefer to leave the organization or move to different roles to get rid of the unequal climate and discriminatory relationship arising from the dark members. Therefore, we argue that the dark side of leadership invokes weak internal auditors' organizational commitment. This research hypothesizes:

H1a: Dark side of leadership is negatively associated with organizational commitment among internal auditors.

Whistleblowing may be described as the disclosure of unlawful, unethical or illegitimate activities by members of an organization (former or current) under the influence of their employers to individuals or organizations that may be able to act (Near \& Miceli, 1995). Indeed, it can be of two kinds: internal and external disclosure. According to Cheng et al. (2019) majority of whistleblowers favor whistleblowing internally over externally (Ahmad et al., 2012; Ahmad, 2011; Habbe et al., 2019; Zhang et al., 2009), Prefer trying the internal channels first before blowing the whistle outside. Accourding to Elias (2008) in general the accounting profession has encouraged internal whistleblowing. Whistleblowing within is a complex phenomenon. Potential whistleblowers can only pick this action when they believe that the potential benefits outweigh the potential costs (Cheng et al., 2019). Hence, the focus of this study is on internal whistleblowing.

Past work also shows that expectations of how an organization promotes whistleblowing and the degree to which the company offers knowledge on where to "blow the whistle" are significant factors influencing the ability of individuals to disclose unethical activities on the job (Keenan, 2002). These whistleblowing seldom happens even though an agency continues to allow internal whistleblowing (Bhal \& 
Dadhich, 2011). Perceptions of retribution or lack of company-wide protection for workers reporting misconduct can also discourage employees from reporting such actions to watchdogs in the organization (Micel et al., 1999). Employees may perceive greater risks when speaking out, particularly if the company adopts a culture in which organizational problems outweigh ethical concerns over practice (Clinard, 1983). This is particularly valid when the company strongly enshrines the misconduct (Miceli \& Near, 1988). Where corruption is deeply enshrined, whistleblowers are more likely to face the repercussions of some sort of job loss, changes in or reduction of duties, close supervision, wage reduction, and ostracism (Alleyne et al., 2013; Miceli \& Near, 1988). Not surprisingly, due to fear of demotion, job loss and even physical damage, there's a general unwillingness to disclose wrongdoing (Alleyne et al., 2013). Whistleblowers are also struggling to find future employment (Beyer, 1989). However, internal auditors can face situations involving conflict of interest when performing their dual-role duties (Ahmad, 2011).

Supervisors have a crucial part in influencing workplace conduct social expectations (Oberfield, 2014), and a major role in shaping a culture of corruption (Hechanova \& Manaois, 2020). The literature on leadership has long identified the possible "dark side" of strong and dominant leadership, where the selfcentered vision of the leader includes ambitions (and/or means to those ambitions) that are at odds with high ethical expectations (House \& Howell, 1992). Padilla et al. (2007) indicated that when poor governance, dishonest leaders, and obedient followers build a "toxic triangle," organizations are more likely to seek destructive ends. Researchers are usually in agreement that leaders often make decisions that hurt followers and long-term organizational success (Bedell-Avers, 2008), underlining this "dark" side of leadership. Following the seminal work of House \& Howell (1992), a number of scholars have begun researching various unstable characteristics, sinister behaviour and adverse consequences correlated with disruptive styles of leadership.

In summary, leaders have the ability to have a direct impact on how workers think about their company, their roles inside the company, and the everyday activities they want to participate. As such, it can be argued that internal auditors working in organizations where dark leaders are most likely to be tolerated do not believe that their organization supports the reporting of dark leadership behaviour. Such auditors may consider whistleblowing behaviour to be inconsistent with organizational policies and objectives. In addition, they may be scared to report to dark leaders for fear of the organization's retaliation. As a result, these auditors can opt to forgo "blowing the whistle" and choose to remain silent instead. Thus, it has been argued that dark leaders may limit the organization's ability to fight and expose wrongdoing specifically, this study hypothesize that:

H1b: Dark side of leadership is negatively associated with whistleblowing intention among internal auditors.

\subsection{Organizational commitment and whistleblowing intention}

The definition of "organizational commitment" has recently become one of the most fascinating and accentuated subjects. Organizational commitment is characterized as the employee's involvement in and affiliation with an organization. It is the method of slowly integrating members with their organization, so that members of the organization are able to work together to preserve their status as members of the organization and to defend and promote the goals and interests of the organization (Chen \& Lai, 2014). Organizational commitment is part of the prosocial theory. Through prosocial theory, human action is geared towards attaining the wellbeing of people, communities, and organizations (Brief \& Motowidlo, 1986). Organizational commitment is a key variable in understanding employee behaviour which has potentially serious implications for the overall performance of the organization and which has been hazardous to the organization (Saadeh \& Suifan, 2020).

Research has also explored extensively the relationship between organizational commitment variables and the ethical behaviour of individuals. Whistleblowing theoretical and empirical studies have recognized that organizational commitment can directly influence whistleblow willingness (Alleyne, 2016; Near \& Miceli, 1985; Somers \& Casal, 1994; Street, 1995; Taylor \& Curtis, 2010). Street (1995) argued that when employees have a high level of organizational commitment, they are more likely to exhibit whistleblowing prosocial behaviour than those with a lower organizational commitment. Near \& Miceli (1985) suggest that the internal reporters in their initial decision to report will demonstrate high levels of 
firm loyalty. Somers \& Casal (1994) indicated that organizational commitment raises the probability of whistleblowing as the whistleblowers identified as reformers seek to get back on track with their organizations. In addition, the analysis carried out by Ahmad et al. (2012) failed to clarify the relationship between organizational commitment and the internal whistleblowing intentions of internal auditors in Malaysia. More work in this field, according to Ahmad et al. (2012), will enhance the value of the internal audit role within the company, thereby fulfilling the shortfall. This study argues that internal auditors with low levels of organizational commitment will be more concerned about themselves and less about the organization. Employees would either not be able to recognize misconduct and face possible harm to themselves, or they will lift the problem quickly without thinking about the harm to the company. As the organizational commitment increases, any attempt to stop illegal/unethical practices will be made prudently, in the hope of helping the organization in a minimally harmful manner, and may be able to observe unethical behaviour or not reluctant to make a whistle. Thus, this study hypothesis that:

H2: Organizational commitment is positively associated with whistleblowing intention among internal auditors.

\subsection{The mediating role of organizational commitment}

The direct effects of the dark side of leadership on internal auditors' organizational commitment and whistleblowing intent were expected. Next, the indirect influence is conjectured in order to fully comprehend its role in the whistleblowing intention of internal auditors. To that end, an intermediary mechanism is used for organizational commitment. Dark leaders in organizations can stimulate stress and reduce the quality of the work environment, and thus it is a vital determinant of internal auditors' organizational commitment and whistleblowing intent. In addition, given the small number of studies on the effect of the negative types or behaviour of the supervisors. As stated in many current organizational behavioural studies, the relationship between coercive supervision and organizational deviant behaviour can be mediated by organizational commitment (Duffy et al., 2002; Guan \& Hsu, 2020). Thus, as one of the implications of dark leadership, this study argues that organizational commitment can be a significant factor when evaluating the effect of dark leadership on the whistleblowing purpose of internal auditors. Accordingly, this study hypothesizes that:

H3: Organizational commitment mediates the relationship between dark side of leadership and internal auditors' whistleblowing intention.

\section{Methodology of research}

This field work used survey methods for data collection, utilizing a well-designed questionnaire instrument to evaluate the theoretical definition and its hypotheses. Information about the design of measurements and our study methodology are addressed in the following sections.

\subsection{Sample and data collection}

In this study, respondents were internal auditors who worked on the Jordanian industrial shareholding companies. Internal auditors were appointed because the quest for and disclosure of financial reporting violations is an ordinary part of the job work. For data collection, this study used a cross-sectional research design. About 150 questionnaires were hand-distributed, and about 122 were collected back. Some them were noticed to have been inadequately answered, and they had been left out of consideration. Lastly, 89 questionnaires returned and 59.3 percent answered.

\subsection{Measurement}

To ensure the questionnaire's reliability and validity, all construct were adapted from previous literature and slightly updated according to the context of our research. Used to assess the internal whistleblowing intention of the internal auditor the 4-item scale established by Park and Blenkinsopp (2009). Organizational commitment was measured using the Organizational Commitment Questionnaire (OCQ) tool developed by Porter et al. (1974). The OCQ has been used by Colbert \& Kwon (2000) and Kwon \& Banks (2004) to measure organizational commitment among internal auditors. The dark side of 
leadership items was adapted from McIntosh \& Rima (1997), capturing perceptions of the degree of inequality and abusive treatment by internal auditors. All items were measured using a 7-point Likert scale, anchored from "1" ("Strongly Disagree") to "7" ("Strongly Agree"), to show the level of agreement between a respondent and the statements. The questionnaire's reliability was measured using test-retest approaches $0.966,0.899$, and 0.901 , respectively. Following this, descriptive and inferential statistics were used to analyze the data.

\section{Data Analysis}

The study model in this work was examined using the partial least squares, structural equation modeling (PLS-SEM). The approach is ideal for the study of path models that are classified as complex where other covariance-based SEM approaches can not provide an approximation (Henseler, 2017). The PLS-SEM was employed in this study due to its suitability in predicting organisational commitment and the effects of whistleblowing intent (Hair et al., 2017).

Data were inserted into SPSS, and SmartPLS analyzes were carried out. PLS-SEM has been increasingly used in literature to provide a description of complex behaviours (Henseler, Hubona, \& Ray, 2016), because of its usefulness in enhancing the explanatory capacity and inter-correlations of the major target variables (Hair et al., 2017). According to Hair et al. (2017), findings can be viewed in two stages: first, the measurement model assessment, and second, the structural model assessment (Al Shbail et al., 2018a,b; Alserhan \& Shbail, 2020; Obeid et al., 2017; Shbail, 2018).

\subsection{Measurement model}

The result of the model measurement meets the minimum criteria (refer Table 1 and Fig. 1 ). In this study, for factor loadings ( $t$-value $>1.96$ and $p$-value $<0.05$ ) a cut-off value of 0.70 is considered important. All item loadings exceeded 0.7, indicating high reliability for indicators (Hair et al., 2017; Al Shbail, 2018 a,b). Furthermore, rho $_{A}$ by Dijkstra-Henseler was used instead of Cronbach alpha and composite reliability, to achieve a reliable estimate of data accuracy and ensure the reliability of construction loads (Ringle et al., 2017). In addition, the AVE values reached the threshold of 0.50 , thereby establishing convergent validity of the constructs (Henseler, 2017; Henseler et al., 2016; Shbail \& Shbail, 2020).

Table 1. Validity and reliability for constructs

\begin{tabular}{ccccccc}
\hline Construct & Code & SD & Loadings & CA & AVE & $\rho_{A}$ \\
\hline \multirow{5}{*}{ Dark Side of Leadership } & DL-1 & 0.013 & 0.886 & & & \\
& DL-2 & 0.015 & 0.887 & & & \\
& DL-3 & 0.014 & 0.911 & & & \\
& DL-4 & 0.014 & 0.905 & & & \\
& DL-5 & 0.030 & 0.833 & 0.966 & 0.784 & 0.971 \\
& DL-6 & 0.021 & 0.877 & & & \\
& DL-7 & 0.016 & 0.904 & & & \\
& DL-8 & 0.030 & 0.864 & & & \\
& DL-9 & 0.018 & 0.900 & & & \\
\hline & OC-1 & 0.047 & 0.832 & & & \\
& OC-2 & 0.052 & 0.774 & & & \\
Organizational Commitment & OC-3 & 0.038 & 0.832 & 0.899 & 0.665 & 0.909 \\
& OC-4 & 0.029 & 0.874 & & & \\
& OC-5 & 0.034 & 0.835 & & & \\
& OC-6 & 0.074 & 0.740 & & & \\
\hline \multirow{5}{*}{ Whistleblowing Intention } & WL-1 & 0.027 & 0.884 & & & \\
& WL-2 & 0.038 & 0.852 & $\mathbf{0 . 9 0 1}$ & $\mathbf{0 . 7 7 1}$ & $\mathbf{0} 0.906$ \\
& WL-3 & 0.024 & 0.887 & & & \\
\hline & WL-4 & 0.028 & 0.889 & & & \\
\hline
\end{tabular}

In this analysis, two parameters were used in the creation of the discriminating validity in the reflective measurement models: the Fornell-Larcker criterion and the heterotrait-monotrait (HTMT) ratio (Henseler et al., 2015). The Fornell-Larcker criterion is met when the AVE square root of each latent 
variable is larger compared to its correlation with the other latent variables (Hair et al., 2017). Table 2 shows the appropriate discriminant validity based on the Fornell-Larcker criterion. In addition, the establishment of discriminant validity on the basis of a suggestion made by Henseler et al. (2015) and AlShbiel et al. (2018), the ratio of HTMT should be 0.85 or 0.9 or less. As can be seen in Table 2, all LVs have values of HTMT below 0.85 . They demonstrate the tolerability of the discriminant validity of the model (Henseler et al., 2015).

Table 2. Discriminant validity

\begin{tabular}{lccc}
\hline Fornell-Larcker criterion & & $\mathbf{2}$ & $\mathbf{3}$ \\
\hline & $\mathbf{1}$ & & \\
\cline { 2 - 3 } Dark Side of Leadership & $\mathbf{0 . 8 8 5}$ & $\mathbf{0 . 8 1 6}$ & $\mathbf{0 . 8 7 8}$ \\
Organizational Commitment & -0.436 & $\mathbf{3}$ \\
Whistleblowing Intention & -0.407 & $\mathbf{2}$ & \\
\hline HTMT criterion & & & \\
\hline & $\mathbf{1}$ & - \\
Dark Side of Leadership & - &
\end{tabular}

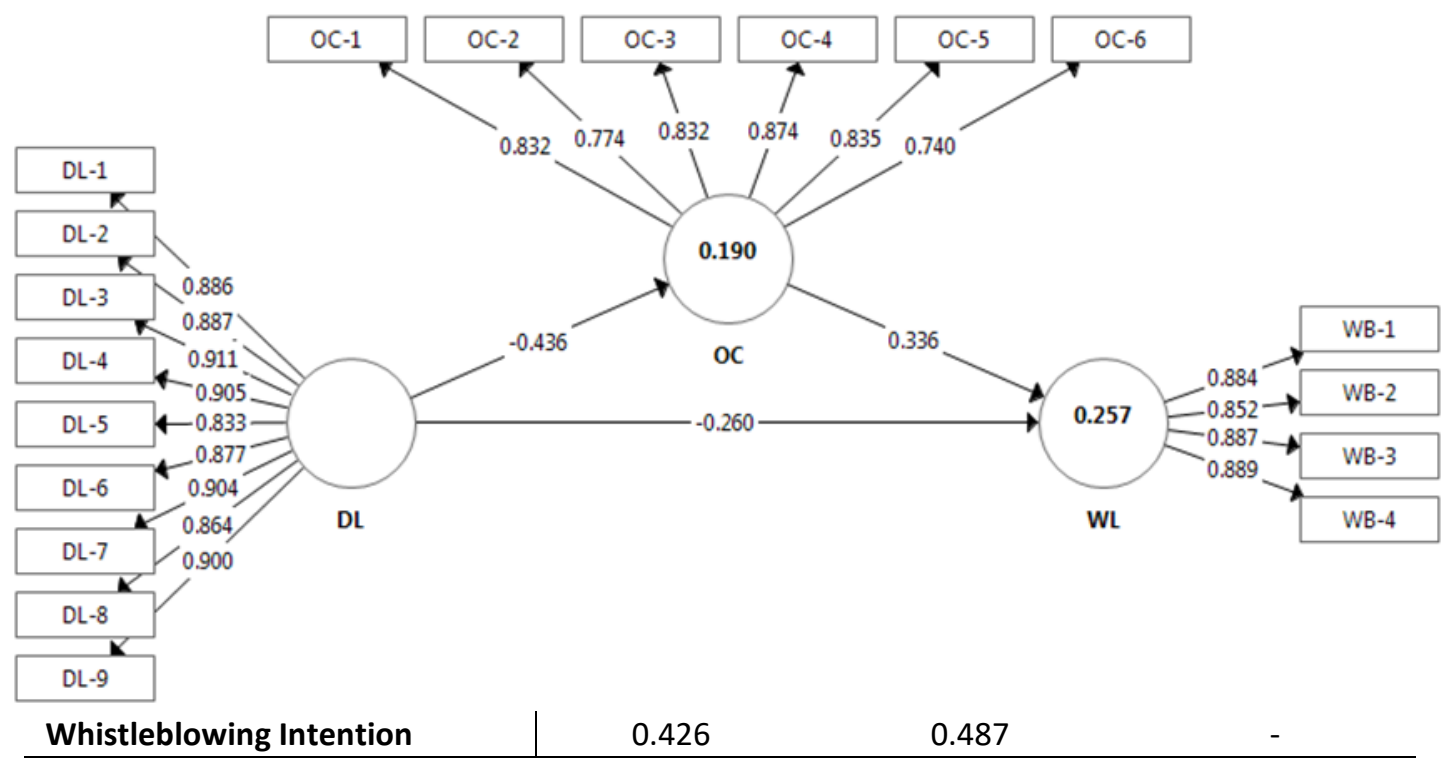

Figure 1. Evaluation of the measurement model

\subsection{Structural model}

Evaluation of the structural model is the second level of PLS-SEM analysis after the measurement process has to be specificated. Structural path model assessment involves evaluating the model's predictive validity and estimation of path coefficients, as well as their statistical significance. This research adopted general recommendations from Hair et al. (2019) for testing the structural model and reporting on the findings.

Henseler et al. (2016) recommended applying percentile bootstrapping to establish a confidence interval of 95 percent in order to achieve the exact result. In this regard, an interval with no zero denotes a structural path coefficient that is significantly different from zero at a confidence level of 95 per cent (Castro \& Roldán, 2015) and the "critical t-values for a two-tailed test were 1.65 with a meaning level of $1.65,1.96$ with a meaning level of $5 \%$, and 2.58 with a meaning level of $1 \%$ ". Such findings fit with most of the suggested relationships about the constructs. Specifically, the dark side of leadership has been shown to have a detrimental and substantial impact on organizational commitment and internal desire to whistleblow. On the contrary, organizational commitment to internal whistleblowing intent has been found to have a positive one. 
Table 3. Model predictive capabilities

\begin{tabular}{l|c|c|c|c|c|c}
\hline \multicolumn{1}{c|}{ Constructs } & $\mathbf{R}^{2}$ & Adj. $^{2}$ & $f^{2}$ & $\mathbf{Q}^{2}$ & SRMR & RMS theta \\
\hline Dark Side of Leadership & - & - & 0.074 & - & - & - \\
\hline Organizational Commitment & 0.190 & 0.181 & 0.123 & 0.115 & - & - \\
\hline Whistleblowing Intention & 0.257 & 0.240 & - & 0.177 & 0.058 & 0.115 \\
\hline
\end{tabular}

Table 4. Results of hypothesis testing

\begin{tabular}{ccccc}
\hline Hypothesis & Beta and $t$ value & 95\% confidence intervals & P value & Decision \\
\hline H1: DL->OC & $-0.436(4.704)$ & $(-0.623 ;-0.253)$ Sig & 0.000 & Supported \\
H1b: DL-> WL & $-0.260(2.033)$ & $(-0.521 ;-0.014)$ Sig & 0.043 & Supported \\
H2: OC-> WL & $0.336(2.406)$ & $(0.067 ; 0.611) \mathrm{Sig}$ & 0.017 & Supported \\
\hline
\end{tabular}

\subsection{Mediation test}

The next step included the estimation of the indirect effect importance, and this called for the use of the evaluation of the proposed model by SEM, enabling the measurement of the relationships of variables of the model and the testing of the hypotheses proposed. Therefore, the mediation hypothesis (H3) was tested based on Hair et al. (2017) procedures. In that respect, the determination of the mediating effect requires four conditions to be met; 1 ) the DV is affected by the IV; 2 ) the IV is affected by the mediating variable; 3 ) the DV is affected by the mediating variable; and 4) the impact of IV on the DV shall be excluded or mitigated by a mediating effect.

Table 5. Mediation test

\begin{tabular}{cccccccc}
\hline \multirow{2}{*}{ Hypothesis } & a & b & a*b & C & C' & \multicolumn{2}{c}{ Method } \\
\cline { 2 - 8 } & Path & Path & Path & Path & Path & Variance accounted for (VAF) & Boot-strapping \\
\hline DL -> OC-> WL & -0.436 & 0.336 & -0.147 & -0.407 & -0.260 & 0.36 & Partial mediation \\
\hline
\end{tabular}

More precisely, when the indirect $a \times b$ effect is important, the mediating effect is present (Nitzl, 2016). For this analysis, two forms of mediation, namely complete and partial mediation, are noteworthy. Partial mediation occurs where the direct effect $c^{\prime}$ is significant, while the indirect effect $a \times b$ is also significant (Nitzl, Roldan \& Cepeda, 2016). The indirect-to-total impact in the ratio-terms (Nitzl \& Hirsch, 2016) referred to as the VAF value is measured using VAF. In comparison, the value of the VAF is determined by dividing the indirect effect -0.147 by a total effect of -0.407 equal to 0.361 (36.1\%), ranging between $20-80 \%$. That indicates that, according to Hair et al. (2017), the mediating influence was partial.

\section{Discussions and Conclusions}

In this study, the relationships between the variables of leadership's dark side behaviour, organizational commitment, and the intention of whistleblowing the internal auditor were theoretically explained, and then examined. In fact, the aim of this study was to examine the potential impact and possible impact of the dark side of leadership on internal auditors' whistleblowing intention regarding organizational commitment. The results showed that the dark side of the leadership not only had a direct negative impact on the intention of whistleblowing, but it also indirectly affects the intention of whistleblowing through the organizational commitment of the internal auditor. Another finding of the study indicated that the model suggested was appropriate.

On a realistic standpoint, companies and administrators should recognize that whistleblowing can remedy misdeeds, and action will be taken to allow internal auditors to whistleblow. Our findings give insights into how to internal whistleblowing by internal auditors can be reinforced through organizational commitment. Creating and maintaining a strong organizational commitment is a comprehensive and longterm goal. The managers should serve as ethical models and set an ethical precedent and actions to create trust in their company among internal auditors. Organizations should set up a transparent whistleblowing program to include secure and accessible whistleblowing outlets and make efforts to ensure whistleblowers' protection from retribution by wrongdoers and other stakeholders. If the misconduct is verified, appropriate disciplinary steps should be taken. 
This study has certain limitations which need to be addressed in future research. From a methodological point of view, the model was created using longitudinal data during study. This study used survey design and measured self-reported whistleblowing intent. Although research usually supports the legitimacy of self-reports regarding ethical problems at work, it is also important to be mindful that selfreporting is susceptible to lenient bias that precludes any clear inferences of causality. This analysis has used a survey restricted to internal auditors of the Jordanian public shareholding company. This scope hinders the opportunity to generalize the hypothesis into other countries and regions. In this study a second limitation is the sample size. This study specifically uses small samples, which could jeopardize the generalizability of the results for the entire population (Krejcie \& Morgan, 1970).

\section{References}

1. Ahmad, S., Smith, G., \& Ismail, Z. (2012). Internal whistle-blowing intentions: A study of demographic and individual factors. Journal of Modern Accounting and Auditing, 8(11), 1632-1645. https://ro.ecu.edu.au/ecuworks2012/638

2. Ahmad, S. A. (2011). Internal auditors and internal whistleblowing intentions: A study of organisational, individual, situational and demographic factors. Doctor of Philosophy Thesis, Edith Cowan University, Western Australia.

3. Ahmad, S. A., Yunos, R. M., Ahmad, R. A. R., \& Sanusi, Z. M. (2014). Whistleblowing behaviour: The influence of ethical climates theory. Procedia-Social and Behavioral Sciences, 164, 445-450. https://doi.org/10.1016/j.sbspro.2014.11.101

4. Al-Shbiel, S. O., Ahmad, M. A., Al-Shbail, A. M., Al-Mawali, H., \& Al-Shbail, M. O. (2018). The mediating role of work engagement in the relationship between organizational justice and junior accountants' turnover intentions. Academy of Accounting \& Financial Studies Journal, 22(1), 1-23.

5. Al Shbail, M., Salleh, Z., \& Nor, M. (2018). The effect of ethical tension and time pressure on job burnout and premature sign-off. Journal of Business and Retail Management Research, 12(4), 43-53. https://doi.org/10.24052/JBRMR\%2FV12IS04\%2FART-05

6. Al Shbail, M., Salleh, Z., \& Nor, M. (2018). Antecedents of burnout and its relationship to internal audit quality. Business and Economic Horizons (BEH), 14(4), 789-817. https://doi.org/10.22004/ag.econ.287230

7. Alleyne, P. (2016). The influence of organisational commitment and corporate ethical values on non-public accountants' whistle-blowing intentions in Barbados. Journal of Applied Accounting Research, 17(2), 190-210. https://doi.org/10.1108/JAAR-12-2013-0118

8. Alleyne, P., Hudaib, M., \& Pike, R. (2013). Towards a conceptual model of whistle-blowing intentions among external auditors. The British Accounting Review, 45(1), 10-23. https://doi.org/10.1016/j.bar.2012.12.003

9. Alserhan, H., \& Shbail, M. (2020). The role of organizational commitment in the relationship between human resource management practices and competitive advantage in Jordanian private universities. Management Science Letters, 10(16), 3757-3766. https://doi.org/10.5267/j.msl.2020.7.036

10.Institute of Internal Auditors (IIA). (2016). International Standards for the Professional Practice of Internal Auditing.

11.Arnold, D. F., \& Ponemon, L. A. (1991). Internal auditors' perceptions of whistle-blowing and the influence of moral reasoning: An experiment. Auditing: A journal of practice, 10(2), 1-15. http://hdl.handle.net/10822/848968

12.Aryee, S., Chen, Z. X., Sun, L.-Y., \& Debrah, Y. A. (2007). Antecedents and outcomes of abusive supervision: test of a trickle-down model. Journal of applied psychology, 92(1), 191-201. https://doi.org/10.1037/0021-9010.92.1.191

13.Bedell-Avers, K. (2008). Leader errors: An examination of the implication. Doctoral dissertation, University of Oklahoma.

14.Beyer, J. M. (1989). The Whistleblowers: Exposing Corruption in Government and Industry. Science, 244(4906), 835-837. 
15.Bhal, K. T., \& Dadhich, A. (2011). Impact of ethical leadership and leader-member exchange on whistle blowing: The moderating impact of the moral intensity of the issue. Journal of Business Ethics, 103(3), 485. https://doi.org/10.1007/s10551-011-0876-z

16.Bhandarker, A., \& Rai, S. (2019). Toxic leadership: emotional distress and coping strategy. International Journal of Organization Theory \& Behavior, 22(1), 65-78. https://doi.org/10.1108/IJOTB-032018-0027

17.Bligh, M. C., \& Hess, G. D. (2007). The power of leading subtly: Alan Greenspan, rhetorical leadership, and monetary policy. The Leadership Quarterly, 18(2), 87-104. https://doi.org/10.1016/j.leaqua.2007.01.001

18.Bligh, M. C., Kohles, J. C., Pearce, C. L., Justin, J. E., \& Stovall, J. F. (2007). When the romance is over: Follower perspectives of aversive leadership. Applied Psychology, 56(4), 528-557. https://doi.org/10.1111/j.1464-0597.2007.00303.x

19.Brief, A. P., \& Motowidlo, S. J. (1986). Prosocial organizational behaviors. Academy of management Review, 11(4), 710-725. https://doi.org/10.5465/amr.1986.4283909

20.Carcello, J. V., Hermanson, D. R., \& Ye, Z. (2011). Corporate governance research in accounting and auditing: Insights, practice implications, and future research directions. Auditing: A Journal of Practice \& Theory, 30(3), 1-31. https://doi.org/10.2308/ajpt-10112

21.Chen, C. P., \& Lai, C. T. (2014). To blow or not to blow the whistle: The effects of potential harm, social pressure and organisational commitment on whistleblowing intention and behaviour. Business Ethics: A European Review, 23(3), 327-342. https://doi.org/10.1111/beer.12053

22.Chen, Y., Zhou, X., \& Klyver, K. (2019). Collective efficacy: Linking paternalistic leadership to organizational commitment. Journal of Business Ethics, 159(2), 587-603. https://doi.org/10.1007/s10551018-3847-9

23.Cheng, J., Bai, H., \& Yang, X. (2019). Ethical leadership and internal whistleblowing: A mediated moderation model. Journal of Business Ethics, 155(1), 115-130. https://doi.org/10.1007/s10551-017-3517-3

24.Chiasson, M., Johnson, G. H., \& Byington, J. R. (1995). Blowing the whistle: Accountants in industry. The CPA Journal, 65(2), 24-25.

25.Clinard, M. B. (1983). Corporate ethics and crime: The role of middle management. Beverly Hills: Sage Publications.

26.Colbert, A. E., \& Kwon, I.-W. G. (2000). Factors related to the organizational commitment of college and university auditors. Journal of managerial issues, 484-501. https://www.jstor.org/stable/40604326

27.Dhamija, S., \& Rai, S. (2018). Role of retaliation and value orientation in whistleblowing intentions. Asian Journal of Business Ethics, 7(1), 37-52. https://doi.org/10.1007/s13520-017-0078-6

28.Duffy, M. K., Ganster, D. C., \& Pagon, M. (2002). Social undermining in the workplace. Academy of Management Journal, 45(2), 331-351. https://doi.org/10.5465/3069350

29.Einarsen, S., Aasland, M. S., \& Skogstad, A. (2007). Destructive leadership behaviour: A definition and conceptual model. The Leadership Quarterly, 18(3), 207-216. https://doi.org/10.1016/j.leaqua.2007.03.002

30.Elias, R. (2008). Auditing students' professional commitment and anticipatory socialization and their relationship to whistleblowing. Managerial Auditing Journal, 23(3), 283-294. https://doi.org/10.1108/02686900810857721

31.Guan, B., \& Hsu, C. (2020). The role of abusive supervision and organizational commitment on employees' information security policy noncompliance intention. Internet research. In press. https://doi.org/10.1108/INTR-06-2019-0260

32.Habbe, A. H., Rasyid, S., Arif, H., \& Muda, I. (2019). Measuring internal auditor's intention to blow the whistle (a Quasi-experiment of internal auditors in the local government). Business: Theory and Practice, 20, 224-233. https://doi.org/10.3846/btp.2019.22

33.Hair, J., F, Hult, G., Ringle, C., \& Sarstedt, M. (2017). A primer on partial least squares structural equation modeling (PLS-SEM) $\left(2^{\text {nd }} e d\right)$. Thousand Oaks, CA: Sage.

34.Hair, J. F., Ringle, C. M., \& Sarstedt, M. (2011). PLS-SEM: indeed a silver bullet. Journal of Marketing Theory and Practice, 19(2), 137-149. https://doi.org/10.2753/mtp1069-6679190202 
35.Hair, J. F., Risher, J. J., Sarstedt, M., \& Ringle, C. M. (2019). When to use and how to report the results of PLS-SEM. European Business Review, 31(1), 2-24. https://doi.org/10.1108/EBR-11-2018-0203

36. Hechanova, M. R. M., \& Manaois, J. O. (2020). Blowing the whistle on workplace corruption: the role of ethical leadership. International Journal of Law and Management, 62(3), 277-294. https://doi.org/10.1108/IJLMA-02-2019-0038

37. Henseler, J. (2017). Bridging design and behavioral research with variance-based structural $\begin{array}{llll}\text { equation modeling. Journal of } & \text { 178-192. }\end{array}$ https://doi.org/10.1080/00913367.2017.1281780

38. Henseler, J., Hubona, G., \& Ray, P. (2016). Using PLS path modeling in new technology research: updated guidelines. Industrial Management \& Data Systems, 116(1), 2-20. https://doi.org/10.1108/IMDS09-2015-0382

39. Henseler, J., Ringle, C. M., \& Sarstedt, M. (2015). A new criterion for assessing discriminant validity in variance-based structural equation modeling. Journal of the Academy of Marketing Science, 43(1), 115-135. https://doi.org/10.1007/s11747-014-0403-8

40. Hoobler, J. M., \& Hu, J. (2013). A model of injustice, abusive supervision, and negative affect. The Leadership Quarterly, 24(1), 256-269. https://doi.org/10.1016/j.leaqua.2012.11.005

41.House, R. J., \& Howell, J. M. (1992). Personality and charismatic leadership. The Leadership Quarterly, 3(2), 81-108. https://doi.org/10.1016/1048-9843(92)90028-E

42.Keenan, J. P. (2002). Whistleblowing: A study of managerial differences. Employee responsibilities and rights journal, 14(1), 17-32. https://doi.org/10.1023/A:1015796528233

43.Kellerman, B. (2004). Bad leadership: What it is, how it happens, why it matters. Harvard Business Press.

44.Kılıç, M., \& Günsel, A. (2019). The dark side of the leadership: The effects of toxic leaders on employees. European Journal of Social Sciences, 2(2), 51-56. http://dx.doi.org/10.26417/ejss-2019.v2i2-64

45.Kilroy, S., Chênevert, D., \& Bosak, J. (2016). Destructive Leadership, Burnout and Affective Commitment among Nurses. Paper presented at the Academy of Management Proceedings. https://doi.org/10.5465/ambpp.2016.16299abstract

46.Kim, S., \& Shin, M. (2019). Transformational leadership behaviors, the empowering process, and organizational commitment: investigating the moderating role of organizational structure in Korea. The International Journal of Human Resource Management, 30(2), 251-275. https://doi.org/10.1080/09585192.2016.1278253

47.Krasikova, D. V., Green, S. G., \& LeBreton, J. M. (2013). Destructive leadership: A theoretical review, integration, and future research agenda. Journal of Management, 39(5), 1308-1338. https://doi.org/10.1177/0149206312471388

48.Krejcie, R. V., \& Morgan, D. W. (1970). Determining sample size for research activities. Educational and Psychological measurement, 30(3), 607-610. https://doi.org/10.1177/001316447003000308

49.Kurtz, H. I., Robbins, A., Westin, A. F., \& Rights, E. F. f. I. (1981). Whistle blowing: Loyalty and dissent in the corporation. New York: McGraw-Hill.

50.Kwon, I.-W. G., \& Banks, D. W. (2004). Factors related to the organizational and professional commitment of internal auditors. Managerial Auditing Journal, 19(5), 606-622. https://doi.org/10.1108/02686900410537748

51.Liyanarachchi, G. A., \& Adler, R. (2011). Accountants' whistle-blowing intentions: The impact of retaliation, age, and gender. Australian Accounting Review, 21(2), 167-182. https://doi.org/10.1111/j.18352561.2011.00134.x

52.McIntosh, G. L., \& Rima, S. D. (1997). Overcoming the Darkside of Leadership. Baker Books.

53.Miceli, M. P., \& Near, J. P. (1988). Individual and situational correlates of whistle-blowing. Personnel psychology, 41(2), 267-281. https://doi.org/10.1111/j.1744-6570.1988.tb02385.x

54.Miceli, M. P., Near, J. P., \& Schwenk, C. R. (1991). Who blows the whistle and why?. IIr Review, 45(1), 113-130. https://doi.org/10.1177/001979399104500108

55.Miceli, M. P., Rehg, M., Near, J. P., \& Ryan, K. C. (1999). Can laws protect whistle-blowers? Results of a naturally occurring field experiment. Work and Occupations, 26(1), 129-151. https://doi.org/10.1177/0730888499026001007 
56. Miethe, T. D., \& Rothschild, J. (1994). Whistleblowing and the control of organizational misconduct. Sociological Inquiry, 64(3), 322-347. https://doi.org/10.1111/j.1475-682X.1994.tb00395.x

57.Near, J. P., \& Miceli, M. P. (1985). Organizational dissidence: The case of whistle-blowing. Journal of Business Ethics, 4(1), 1-16. https://doi.org/10.1007/BF00382668

58.Near, J. P., \& Miceli, M. P. (1995). Effective-whistle blowing. Academy of management Review, 20(3), 679-708. https://doi.org/10.5465/amr.1995.9508080334

59.Nitzl, C. (2016). The use of partial least squares structural equation modelling (PLS-SEM) in management accounting research: Directions for future theory development. Journal of Accounting Literature, 37, 19-35. https://doi.org/10.1016/j.acclit.2016.09.003

60.Nitzl, C., \& Hirsch, B. (2016). The drivers of a superior's trust formation in his subordinate: The manager-management accountant example. Journal of Accounting \& Organizational Change, 12(4), 472503. https://doi.org/10.1108/JAOC-07-2015-0058

61.Nitzl, C., Roldan, J. L., \& Cepeda, G. (2016). Mediation analysis in partial least squares path modeling: Helping researchers discuss more sophisticated models. Industrial Management \& Data Systems, 116(9), 1849-1864. https://doi.org/10.1108/IMDS-07-2015-0302

62.Obeid, M., Salleh, Z., \& Nor, M. (2017). The mediating effect of job satisfaction on the relationship between personality traits and premature sign-off. Academy of Accounting and Financial Studies Journal, 21(2), 1-17.

63.Oberfield, Z. W. (2014). Public management in time: A longitudinal examination of the full range of leadership theory. Journal of Public Administration Research and Theory, 24(2), 407-429. https://doi.org/10.1093/jopart/mus060

64.Padilla, A., Hogan, R., \& Kaiser, R. B. (2007). The toxic triangle: Destructive leaders, susceptible followers, and conducive environments. The Leadership Quarterly, 18(3), 176-194. https://doi.org/10.1016/j.leaqua.2007.03.001

65.Park, H., \& Blenkinsopp, J. (2009). Whistleblowing as planned behavior-A survey of South Korean police officers. Journal of Business Ethics, 85(4), 545-556. https://doi.org/10.1007/s10551-008-9788-y

66.Porter, L. W., Steers, R. M., Mowday, R. T., \& Boulian, P. V. (1974). Organizational commitment, job satisfaction, and turnover among psychiatric technicians. Journal of applied psychology, 59(5), 603-609. https://doi.org/10.1037/h0037335

67.Read, W. J., \& Rama, D. (2003). Whistle-blowing to internal auditors. Managerial Auditing Journal, 18(5), 354-362. https://doi.org/10.1108/02686900310476828

68. Ringle, C., Wende, S., Becker, J., \& GmbH, R. (2017). SmartPLS - Statistical Software For Structural Equation Modeling [Internet]. Smartpls.com. 2017 [cited 2020 Jan 28]. Available from: http://www.smartpls.com

69.Saadeh, I. M., \& Suifan, T. S. (2020). Job stress and organizational commitment in hospitals: The mediating role of perceived organizational support. International Journal of Organizational Analysis, 28(1), 226-242. https://doi.org/10.1108/IJOA-11-2018-1597

70.Shbail, M., \& Shbail, A. (2020). Organizational climate, organizational citizenship behaviour and turnover intention: Evidence from Jordan. Management Science Letters, 10(16), 3749-3756. https://doi.org/10.5267/j.msl.2020.7.037

71.Shbail, M. O. A. (2018). The Effect of Role Ambiguity and Role Conflict on Dysfunctional Audit Behaviour: Evidence from Jordan. International Journal of Academic Research in Accounting, Finance and Management Sciences, 8(3), 17-25. https://doi.org/10.6007/IJARAFMS/v8-i3/4448

72.Smaili, N., \& Arroyo, P. (2019). Categorization of whistleblowers using the whistleblowing triangle. Journal of Business Ethics, 157(1), 95-117. https://doi.org/10.1007/s10551-017-3663-7

73.Somers, M. J., \& Casal, J. C. (1994). Organizational commitment and whistle-blowing: A test of the reformer and the organization man hypotheses. Group \& Organization Management, 19(3), 270-284. https://doi.org/10.1177/1059601194193003

74.Street, M. D. (1995). Cognitive moral development and organizational commitment: Two potential predictors of whistle-blowing. Journal of Applied Business Research (JABR), 11(4), 104-110. https://doi.org/10.19030/jabr.v11i4.5853 
75.Taylor, E. Z., \& Curtis, M. B. (2010). An examination of the layers of workplace influences in ethical judgments: Whistleblowing likelihood and perseverance in public accounting. Journal of Business Ethics, 93(1), 21-37. https://doi.org/10.1007/s10551-009-0179-9

76.Tepper, B. J. (2000). Consequences of abusive supervision. Academy of Management Journal, 43(2), 178-190. https://doi.org/10.5465/1556375

77.Tepper, B. J., Carr, J. C., Breaux, D. M., Geider, S., Hu, C., \& Hua, W. (2009). Abusive supervision, intentions to quit, and employees' workplace deviance: A power/dependence analysis. Organizational behavior and human decision processes, 109(2), 156-167. https://doi.org/10.1016/j.obhdp.2009.03.004

78.Tepper, B. J., Henle, C. A., Lambert, L. S., Giacalone, R. A., \& Duffy, M. K. (2008). Abusive supervision and subordinates' organization deviance. Journal of applied psychology, 93(4), 721-732. https://doi.org/10.1037/0021-9010.93.4.721

79.Treviño, L. K., Brown, M., \& Hartman, L. P. (2003). A qualitative investigation of perceived executive ethical leadership: Perceptions from inside and outside the executive suite. Human relations, 56(1), 5-37. https://doi.org/10.1177/0018726703056001448

80.Weaver, S. G., \& Yancey, G. B. (2010). The impact of dark leadership on organizational commitment and turnover. Leadership Review, 10, 104-124.

81.Xu, Y., \& Ziegenfuss, D. E. (2008). Reward systems, moral reasoning, and internal auditors' reporting wrongdoing. Journal of Business and Psychology, 22(4), 323-331. https://doi.org/10.1007/s10869008-9072-2

82.Zhang, J., Chiu, R., \& Wei, L. (2009). Decision-making process of internal whistleblowing behavior in China: Empirical evidence and implications. Journal of Business Ethics, 88(1), 25-41. https://doi.org/10.1007/s10551-008-9831-z

83.Zheng, B. Z., Patel, C., \& Evans, E. (2019). The influence of construal of self on internal auditors' judgments on whistle-blowing: Evidence from China. International Journal of Auditing, 23(1), 73-85. https://doi.org/10.1111/ijau.12146 